\title{
Chemical/Biological Terrorism: An Old, But Growing Threat in the Middle East and Elsewhere
}

\author{
Dany Shoham Begin-Sadat Center for Strategic Studies, Israel
}

$\mathbf{T}$ he title of Jonathan Tucker's article expresses a thematically improper view-chemical/biological (C/B) terrorism is not really a new threat. I would say it is an increasing threat that at present poses a menace that indeed ought to be practically and expediently dealt with. The probability for this menace to materialize widely is now higher than ever before in relative terms, is fairly obvious in absolute terms, and is currently intensifying.

Production of $\mathrm{C} / \mathrm{B}$ weapons by terrorists themselves is not as important as it seems from the article. Many industrial or laboratory toxic materials can readily be obtained (in quantities, accumulatively) or stolen, and can be used for terrorism. In other words, production constraints are not at all a limiting factor for terrorists.

Further to the modes of $\mathrm{C} / \mathrm{B}$ terrorism listed by Tucker, we may identify the following additional modes:

- blowing up installations where toxic materials are held in gaseous (or liquid) form;

- infiltrating (abruptly or gradually) harmful or toxic $\mathrm{C} / \mathrm{B}$ contaminants into any publicly consumable system or population, including infiltration of drugs as weapons;

- threatening (without necessarily executing) an act of $\mathrm{C} / \mathrm{B}$ terrorism for blackmail, to cause panic or demoralization, or for some other purpose;

- using animal or plant pathogens (as in agriculture) to wreak economic havoc; and

- using $\mathrm{C} / \mathrm{B}$ agents to assassinate selected or random individuals.

Tucker devotes a great deal of attention to nerve agents; that is undoubtedly correct in terms of military utility, but for terrorism, other much simpler chemical agents, such as phosgene or cyanic acid, are not less useful.

Another aspect worth drawing attention to is the feasibility of domestic as opposed to foreign $\mathrm{C} / \mathrm{B}$ terrorism. In this regard, it should be mentioned that a recent poll by the

Dany Shoham is a rescarcher at Begin-Sadat (BESA) Center for Strategic Studies, Bar-Ilan University, Israel. He investigates chemical and biological warfare in Arab couritries and around the world. Formerly, he was a senior analyst and lieutenant colonel in military intelligence. Dr. Shoham received a Ph.D. in medical microbiology from Tel-Aviv University. He has published 16 articles on virology and a monograph on chemical weapons in Syria and Egypt. Correspondence should be addressed to Helsinki 8, Tel Aviv, Israel.
Washington-based Pew Research Center found that a large number of American citizens were concerned about both domestic- and foreign-based $\mathrm{C} / \mathrm{B}$ terrorism (Insight, June 17, 1996).

Tucker's article includes an appropriate demonstration of a chemical incident-the Bhopal incident-but an equivalent example of a biological incident is lacking.

A large portion of the technical information included in the article comprises basics of $\mathrm{C} / \mathrm{B}$ weapons in general (found in many textbooks) and is not concretely related to terrorism. On the other hand, some essential references are not cited at all (for example, Douglass and Livingstone, 1987; Simon, 1989; Burck and Flowerree, 1991; Collins, 1995; Eitzen, 1995; Olson, 1995; Norqvist, 1995; Purver, 1995; Smith et al., 1995).

Regarding Tucker's section on Israel, almost half of this section is not actually related to Israel. And regarding the training of Israeli citizens in the use of protective equipment and antidotes during the Gulf War, ordinary citizens in Israel were trained in how to use such protective equipment and antidotes, but ten of them died because of panic, which led to misuse. Also, several cases in which contamination was carried out by Arab terrorists against Israel were not mentioned:

1978 exported Israeli citrus fruits were mercury poisoned by Palestinian terrorists in cooperation with Iraqis;

1983 Israeli Arabs planned to contaminate water sources in the Gallili by poisonous powder;

1985 coffee was contaminated in a military dining room by carbamate pesticide;

1991 in Haifa market, Gerber baby food was contaminated by methomyl pesticide;

1991 drugs consumed by Jewish citizens of Jaffa were contaminated by rodent poison;

$199135 \mathrm{~kg}$ of extremely poisonous pesticides were stolen from the experimental farm of the faculty of agriculture in Rekhovot;

1992 in a minimarket in Jerusalem, a Palestinian worker contaminated various food articles by parathion;

1993 cucumbers were contaminated by parathion in kibbutz Karmia in the Negev;

1994 contamination (unconfirmed) of the Yarkon stream, which caused fish mortality;

1994 contamination (unconfirmed) of bottled drinks in a factory near Tel-Aviv; and 
1995 water consumed by turkeys was contaminated in the agricultural settlement Shalva.

Apparently, no definite connection can be found among those various events, and it would appear that most of them are the outcome of individual initiatives. However, since 1976, various newspapers have reported

- Arab terrorists attempting to acquire nerve gas and bacteriological agents (1976);

- Bader-Mynhoff members training in a Palestinian terrorist camp in Lebanon to use bacteriological weapons, as well as Palestinian terrorists being trained in chemical and biological warfare in USSR (1979) and in guerilla CB weapons applications in East Germany (1985);

- production of chemical agents by Force-17 of the PLO (1988);

- diverse capabilities of Palestinian terrorist organizations to employ CB agents (May 12, 1990, Jane's Defence Weekly); and

- potential threat of $\mathrm{CB}$ weapons use by Middle-Eastern Moslem terrorist groups, as testified by the head of the CIA (April 6, 1995).

Technically, the resources needed for C/B terrorism are clearly available in the Middle East, especially in countries such as Liby a and Iran. The latter, in particular, directing a worldwide advanced terror system, can plausibly assimilate the dimension of $\mathrm{C} / \mathrm{B}$ terrorism into this system locally, in the Middle East, as well as globally.
In summary, the grave trend that characterizes the threat of $\mathrm{C} / \mathrm{B}$ terrorism is quite clear in general, and in regard to the Middle East. Paramount attention should be paid to the possibility that terrorists would attempt to follow the relative operational success that marked the terrorist initiatives recently taken in Japan. The cardinal problem in this concern is seemingly the operational easiness ty pifying such terrorist actions, and, consequently, their actual feasibility.

\section{References}

Burck, G.M. and C.C. Flowerree (1991). International Handbook on Chemical Weapons Proliferation. Westport, CT: Greenwood.

Collins, J.M. (1995). "Weapons of Mass Destruction: The Impact of Proliferation on U.S. Military Posture." Congressional Research Service report for Congress.

Douglass, J.D. and N.C. Livingstone (1987). America the Vulnerable: The Threat of Chemical and Biological Warfare. New York: Free Press.

Eitzen, E. (1995). "Potential Biological Threat Scenarios." Testimony before the U.S. Senate Permanent Subcommittee on Investigation, October 31, Washington, DC.

Norqvist, A. (1995). "Covert Use of BTW: For What Purpose?" Proceedings of the Fifth Intemational Symposium on Protection Against CBW Agents, June, Stockholm.

Olson, K. (1995). Testimony before the U.S. Senate Permanent Subcommittee on Investigation, October 31, Washington, DC.

Purver, R. (1995). Chemical and Biological Terrorism: The Threat According to the Open Literature. Ottawa: Canadian Security Intelligence Service.

Simon, J.D. (1989). Terrorists and the Potential Use of Biological Weapons: A Discussion of Possibilities. The Rand Corporation.

Smith, R.J. et al. (1995). "Can We Prevent the Use of Chemical Weapons by Terrorists?" Medicine and Global Sunival 2:476-89. 